\title{
健常女性の日常生活習慣と運動耐容能
}

亀山 文子, 降谷 初世, 木村 和治, 岸 久幸,
吉崎 英清, 稲次 潤子, 久野 則一

近年女性の間でもテニスクラブや各種のスポーツク ラブに所属して規則的に運動を行なう者が多くみられ るようになった。今回我々の施設において総合健診を 受けた, 生活活動パターンの異なる専業主婦とフルタ イムの職業を持つ兼業主婦およびゴルフ場のキャディ 一について, 運動習慣と運動耐容能および身体組成の 関係を検討した。

〈対象及び方法〉 1985 年 4 月より 1990 年 12 月ま での初回受診者のうち有疾患者, 運動選手を除きトレ ッドミル上の歩行に支障のなかった 20 歳から 59 歳ま での健常女性 432 名を対象とした。うち専業主婦 253 名, 兼業主婦 101 名, キャディー 78 名である。

運動習慣は受診前に記入される問診表より過去 3 力 月以上に軽く汗ばむ程度の運動を 15 分以上行なう回 数を調べ「週 1 回未満」「週 1-2 回」「週 3 回以上」の 3 群に分類した。運動耐容能はトレッドミルによる自 覚的最大運動負荷試験を Balke 法で行ない運動持続 時間（トレッドミル時間）により評価した。対象の負 荷中止理由は下肢疲労または全身的疲労であった。体 脂肪率は皮脂厚 7 点測定法により測定した。

〈結 果〉まず専業主婦 (HW) 群と兼業主婦 (OL) 群について, 運動回数別に身体組成および運動耐容能 を比較した。年齢, 身長, 体重, 体脂肪率に両群間に 有意差はなかった。運動耐容能は OL 群で HW 群より 高い傾向はあるが有意差はなかった。そこで以後 OL 群と HW 群をまとめて一般女性 (W) 群とし, 年代別 に身体組成および運動耐容能を検討した。

$\mathrm{W}$ 群の体重は各年代間に差はなかったが, 体脂肪率
は年代が高いほど大きかった。運動耐容能は年代が高 いほど低かった。

次に年代別に $\mathrm{W}$ 群とキャディー $(\mathrm{C})$ 群を比較した。 なお $\mathrm{C}$ 群は万歩計による計測で 1 日平均 2.5 万歩, 週 に 5 日歩行し，仕事以外に規則的に運動を行っている 者はなかった。まず運動の回数別にみた $\mathrm{W}$ 群の体脂 肪率は各年代とも週 3 回以上運動する群は他の 2 群に 比し有意に小さかった。C 群の体脂肪率は各年代の運 動習慣のない群に相当した。次に運動の回数別にみた $\mathrm{W}$ 群の運動而容能は各年代とも運動の回数が多い群 ほど高かった。C 群の運動耐容能は各年代の運動回数 の多い群に相当した。

〈まとめ〉 総合健診を受診した 20 歳から 59 歳の健 常女性 432 名の運動習慣と身体組成及び運動耐容能を 比較検討した。その結果，1）HW 群とOL 群では身 体組成と運動耐容能に有意差はなかった。2) W 群を 年代別に比較すると体重に差はなかったが体脂肪率は 年代が高いほど有意に大きかった。運動耐容能は年代 が高いほど有意に低かった。3)C 群を W 群と比較す ると, 体脂肪率は $\mathrm{W}$ 群の運動回数の少ない群に相当 し, 運動耐容能は $\mathrm{W}$ 群の運動回数の多い群に相当し た。

一般女性群では規則的な運動習慣のある者は運動耐 容能が高く体脂肪率は小さいが, 重労働者であるキャ ディー群では運動耐容能は高いが体脂肪率は大きく, 今後食事内容の検討や生活指導後の追跡検討などが必 要と思われた。

\section{Daily Exercise Habit and Endurance Power in Healthy Female}

エアロビクスクリニック

国立健康・栄養研究所 